Dept. of Food Hygiene,

Fac. of Vet. Med. Assiut University

Head of Dept. Prof. Dr. H. Youssef

\title{
LEVEL OF GAMMA RADIATION IN SOME SELECTED FOOD ITEMS
}

(With One Tables)

\author{
By \\ SH.M. FATHI; NAGAH. M. SAAD \\ and M.N. ISMAIL
}

(Received at 23\2\1995)

$$
\text { مستوى الشعاعات جاما فى بعض المنتجات الفذائيه }
$$

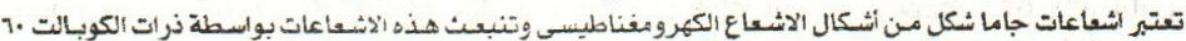

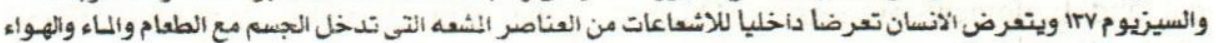

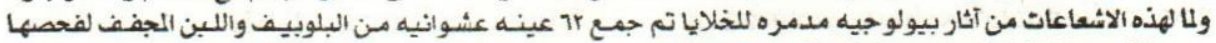

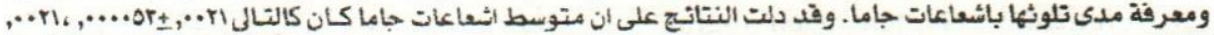

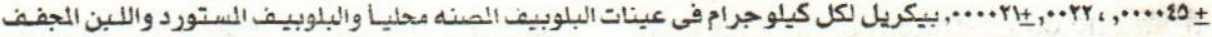

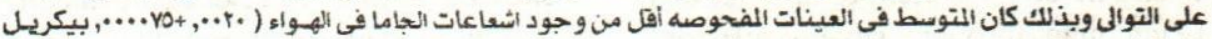

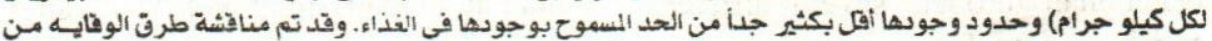

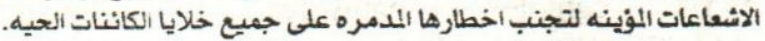

\section{SUMMARY}

Sixty- two randome samples of corned beef and milk powder were analyzed for gamma radiation. The obtained results indicated that the mean levels of gamma radiation were $0.0021 \pm 0.00053,0.0021 \pm 0.000045$ and $0.0022 \pm 0.000021 \mathrm{~Bq} / \mathrm{Kg}$ in the examined samples of local processed and imported corned beef and milk powder, respectively. Gamma radiation level of all types of the examined samples were within the normal rate in comparison with mean level of the back ground (air) $0.0020 \pm 0.000075 \mathrm{Bk} / \mathrm{Kg}$., but lower than the maximum concentration in foods. The public health importance of gamma radionuclides was discussed.

Keywords: Level of gamma radiation in some selected food items

\section{INTRODUCTION}

Radiation refers to a physical phenomenon in which energy travels through space or matter. Irradiation is the process of this energy to a material.

Radionuclides enter the environment in several ways. Primordal isotopes are very long lived (with half-lives comparable to the age of 
the Earth $10^{9}$ to $10^{11}$ years or longer), Cosmogenic nuclides are formed by the interaction of cosmic rays with the gases in the upper atmosphere. Artificial nuclides are those that produced by nuclear reaction and have entered the environment both from the denotation of nuclear weapons, particularly atmospheric tests and from the industrialscale manufacture, use and reprocessing of nuclear material, principally fissile material for weapons and fuel for reactors (LIVENS and RIMMER, 1989).

The entry of radiocontaminant into the environment alters the dynamic eqilibrium of many physical, chemi$\mathrm{cal}$ and biological processes. Once the radionuclides have entered the environmental recipient, can migrate from one compartment to another and reach man through several different and complex pathways (MANSCANZONI, 1987).

Among foods, milk is considered the major source and radionuclides in the food chain to children and a significant contributor to radioisotope ingesion level in adults. These are of concern because cells of the body may be damaged by gamma rays.

Gamma rays are produced by radioactive isotopes such as Caesium 137 and Cobalt 60 MENZEL. 1963).

Milk may become contaiminated when cows ingest feeds from plants that bear. fallout on their sufaces or have absorbed radioactive substances from soil, and the radionuclides can be transferred to products such as cheese made from milk (MENZEL, 1963).

The symptoms in the person ingesting radionuclides depend on the nature and the source and the tendency of certain radionuclides to concentrate in the tissues of important organs. Also, the age of the person and the resistance to the toxic effect of the radionuclides (CHADWICK, 1962).

The maximum concentration of radioactivity permitted foodstuffs offered for sale was settled at 300 $\mathrm{Bq} / \mathrm{Kg}$ fresh weight (NATIONAL FOOD ADMINSTRATION, 1987). MASCONZONI (1987) found that, the content of $137 \mathrm{Cs}$ in milk offered for sale was fairly low, while WIECHES and SCHLIMME (1987) showed a marked effect on contamination of dairy milk with ${ }^{137} \mathrm{Cs}$ after the reactor accident at Chernobyl. AARKROAG et al. (1989) stated that the ${ }^{137} \mathrm{Cs}(\mathrm{Bq} / \mathrm{Kg})$ content in milk was 5.85 , cheese 0.43 and lamb meat 1.07. On the other hand HRUSOVSKY et al. (1989) found that caesium radionuclides in canned meat products increased up to 70 $\mathrm{Bq} / \mathrm{Kg}$ in 1986 , up to $150 \mathrm{~Bq} / \mathrm{Kg}$ early in 1987, and a gradual decline to $40 \mathrm{~Bq} / \mathrm{Kg}$ by the end of 1988 , while in milk products the content was $30 \mathrm{~Bq} / \mathrm{Kg}$, LAKRITZ et al. (1993) stated that gamma irradiation resulted in linear decreases in the alpha tocopherol with increasing dose in fresh muscle tissue and liver from chicken, beef and pork. 


\section{5}

Therefore, this study was aimed to measure the level of gamma radiation in dried milk and corned beef.

\section{MATERIAL and METHODS

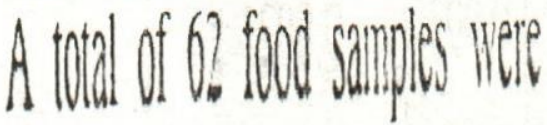

obtained from different localities at Assiut Province. The collected samples were included 42 samples of dried milk and 10 samples from each local processed and imported corned beef.

Each sample was digested according to the technique recommended by FAHMY (1971), where one gram of sample, $5 \mathrm{ml}$ of $50 \%$ sulphuric acid and $5 \mathrm{ml}$ of concentrated nitric acid were added in a clean dry flask. The flasks were heated gently over a low flame of minor-burner until clear fumes of nitric and sulphuric acid appear. The flame was turned off and the flasks allowed to cool.

The digested samples were prepared for filteration by adding diluted $\mathrm{Hcl} \mathrm{N} / 10$. The obtained mixture was filterated through a glass funnel containing filter paper, where the filterate was collected in a glass cylinder.

The previously digested and filterated samples were prepared for measurment the level of gamma radiation in each sample count perminute $(\mathrm{cpm} / \mathrm{min})$ using scaler ratemeter type 6-90 (Burnhan and Crouch-England). Provided by International Atomic Energy Agency, Vienna, Austria.
The obtained results were recorded in Table (1).

\section{DISCUSSION}

Results in Table (1)- illustrate that the mean values for gammarardation

level in local processed, imported comed beef and milk powder samples were $0.0021 \pm 0.000053,0.0021 \pm$ 0.000045 and $0.0022 \pm 0.000021$ $\mathrm{Bq} / \mathrm{Kg}$, respectively. All obtained mean results appeared to be within normal rate in comparison to the mean level of back ground (air) which was $0.0020 \pm 0.00075 \mathrm{~Bq} / \mathrm{Kg}$.

Although maximum level of gamma radiation was high rather than the mean back ground level, the mean level of all types of the examined samples were lower than the back ground level. Our results are in good agreement with those obtained by MASCANZONI (1987), who found that the content of ${ }^{137} \mathrm{Cs}$ in milk were at or below detection limits. Also, ZYKOVA el al. (1989) showed no significant increase in radiation level in food products over $3 \mathrm{yr}$. period. While WIECHES and SCHLIMME (1987) and HRUSOVSKY et al. (1989) found marked effect on contamination of milk and comed meat products after the reactor accident at Chemobyl.

To minimize the effects of fallout in connection with contamination, means of reducing the uptake of radionuclides in soil, preventing entry of radionuclides to animals and removal of radionuclides from milk and foods. 
Table 1: Statistical analytical results of gamma radiation $\mathrm{Bq} / \mathrm{Kg}$ in some selected food items.

\begin{tabular}{|c|c|c|c|c|}
\hline $\begin{array}{c}\text { Types of samples } \\
\text { examined }\end{array}$ & $\begin{array}{c}\text { No.of samples } \\
\text { examined }\end{array}$ & $\min$ & $\max$. & mean S.E. \\
\hline Local processed & 10 & 0.001 & 0.002 & $0.0021 \pm$ \\
Cormed hed & & 9 & 4 & 0.000053 \\
\hline $\begin{array}{c}\text { Imported corned } \\
\text { beef }\end{array}$ & 10 & 0.001 & 0.002 & $0.0021 \pm$ \\
\hline Milk powder & 42 & 0.002 & 0.002 & $0.0022 \pm$ \\
\hline
\end{tabular}

The mean gamma radiation count of back ground (air) was $0.0020 \pm 0.000075 \mathrm{~Bq} / \mathrm{Kg}$.

\section{REFERENCES}

Aarkrog, A.; Buch, E.; Chen, Q.J. ; Christensen, G.C.; Dahlgaard, H.; Hansen, H.; Hol., E. and Nielsen, S.P. (1989): Environmental radioactivity in the North Atlantic region including the Faroe Islands and Greenland Riso Report. R-564, 84pp ISBN 87-550-1533-6.

Chadwick, D.R. (1962): Effects of radioactive contamination of the environment on public health. J. Dairy Sci. 45: 1552-1557.

Fahmy, F. (1971): Studies on factors affecting copper level in Egyptian sheep.

Ph.D. Thesis. Vet. Med., Cairo University, Egypt.

Hrusovsky, J.; Tokosova, M. and Mizik, P. (1989): Contamination of foods by caesium radionuclides. Veterinarni Medicina 34(8): 451-458.

Lakritz, L.; Richardson, R.B. and Thayer, D.W. (1993): Effect of gamma radiation on free alpha tocopherol levels in fresh meat and poultry. Annual Meeting, Book of Abstracts. 26: 91.

Livens, F.R. and Rimmer, D.L. (1989): Chemical reactions of radionuclides in Soils. Journal of the Science of Food and Agriculture, 49: 127-128.

Mascanzoni, D. (1987): Chernobyl's challenge to the environment: A report from Sweden. The Science of the Total Environment, 67: 133-148.

Menzel, R.C. (1963): Factors influencing the biological availability of radionuclides for plants, Fed. Proc. 22: 1393-1401.

National Food Adminstration (1987): Statens Livsmedelsverks Författningssamling, SLv Fs 1987: 4.

Wieches, A. and Schlimme, E. (1987): Radioactive contamination of milk after the reactor accident at Chemobyl. Deutsche Molkerei Zeitung. 108(20): 644-648, 653-655.

Zykova, A.S.: Tellushkina, E.L. and Varonina, T.F. (1989): Radioactivity in atmospheric air and in food products in Moscow (1984-1985). Gigiena i Sanitoriya No. 7: 66-68. 